\title{
Improving Students Learning Outcomes Through Mind Map in Human Reproductive System Topic in Natural Science Learning
}

\author{
Aryani Kadarwati Dewi \\ Natural Science Teacher at State Junior High School (SMPN) 1 South Tambun, Bekasi, Indonesia \\ E-mail: aryanikadarwatidewi@yahoo.co.id \\ ${ }^{*}$ Corresponding Author
}

How to Cite : Dewi, A., K. (2019). Improving Students Learning Outcomes Through Mind Map in Human Reproductive System Topic in Natural Science Learning. International Journal for Educational and Vocational Studies, 1 (7), 702-706

\section{ARTICLE HISTORY}

Received: 13 June 2019

Revised: 28 July 2019

Accepted: 24 September 2019

\section{KEYWORDS}

Classroom Action Research;

Learning Outcomes;

Natural Science Learning;

\begin{abstract}
Natural science learning on the topic of the human reproductive system still gets a low score. That is due to the lack of use of learning media. The purpose of this study is to improve student learning outcomes through the use of mind maps in the topic of the human reproductive system. The research method used was classroom action research with the stages of pre-cycle, cycle 1, and cycle 2. The study was conducted in July 2019 and carried out at State Junior High School 1 South Tambun, Bekasi, Indonesia. The results showed that student learning outcomes increased from pre-cycle to cycle $1(0.50)$ and from cycle 1 to cycle $2(0.59)$ with a moderate gain score category. Whereas the pre-nuclear until cycle $2(0.79)$ has a high gain score category. The use of mind maps is very useful because the reproductive system has many concepts that must be made simple. The conclusion is the use of mind maps can improve student learning outcomes on the topic of the human reproductive system.
\end{abstract}

This is an open access article under the CC-BY-SA license.

\section{INTRODUCTION}

Natural science learning is growing with the various challenges that exist. The $21^{\text {st }}$ century requires students to be able to analyze problems. These problems can be analyzed if students have the correct understanding. The topics discussed in natural science learning such as the environment, humans, animals, and plants require a good understanding of the concept (Coley \& Tanner, 2015; Karaarslan \& Teksöz, 2016; Leong, Mohd Said, Shahrill, \& Perera, 2016). One indicator of learning success can be measured from student learning outcomes. Student learning outcomes are relatively low in natural science learning (Ichsan, Sigit, Miarsyah, Azrai, \& Heryanti, 2019; Wicaksono, Minarti, \& Roshayanti, 2018). Even for topics that are considered simple, sometimes students still do not have high scores in natural science learning.

Abilities such as higher-order thinking skills (HOTS) are needed in natural science learning. The challenges of the $21^{\text {st }}$-century cause students to have abilities that are more than memorizing, but must have HOTS (Garcia, 2015 Saido, Siraj, DeWitt, \& Al-Amedy, 2018; Vidergor \& Krupnik-Gottlieb, 2015; Yeung, 2015; Lubis et al.,2019). However, to reach the HOTS level, students must first increase their understanding as measured by learning outcomes. Usually, students will have difficulty understan- ding complex topics such as the organ system in humans, for example, the human reproductive system.

On this topic, students are required to be able to understand and apply various concepts. Students usually have difficulty in understanding it, so we need the help of a learning medium. In this context, mind map media is an alternative to be used. The characteristics of mind map media that are easy to use and practical have the potential to improve student learning outcomes on the topic of the reproductive system. The use of mind maps is also suitable for applying concepts to difficult learning topics (Daghistan, 2016; Polat, Yavuz, \& Tunc, 2017).

The teacher as a facilitator in learning must be able to solve problems in the classroom (Agustini, 2019; Ariyanto et al., 2019) One of them is through classroom action research. Using classroom action research to solve problems is an effective way to improve student competency in a relatively short amount of time (Ichsan \& Mulyani, 2018; Khoiriyah \& Husamah, 2018; Widiana \& Jampel, 2016). That is because teachers do not need to develop media tools or models first. Based on the problems that have been explained above, the purpose of this study is to improve student learning outcomes using mind maps on the topic of the reproductive system. 


\section{METHODS}

This research was conducted in July 2019 at Junior High School 1 South Tambun, Bekasi, Indonesia. The method used is classroom action research. The sample used consisted of 36 students at 9 th grade. In this study consisted of pre-cycle, cycle 1 and cycle 2 . First, giving the test results of learning outcomes at the pre-cycle stage. In cycle 1, the initial stage of planning is carried out by preparing a learning plan and determining the treatment that will be given. At this stage, it was decided that the treatment used mind map media. Then the treatment is carried out and observation and reflection are carried out. In cycle 2 the same is done. At the evaluation stage, the measurement of student learning outcomes is measured. Learning outcomes are calculated using the formula gain score below. The results of the calculation of the gain score indicate whether or not the increase occurred. The greater the gain score indicates that the increase is significant. The category of a gain score can be seen in table 1 .

Table 1. Category for Gain Scores

\begin{tabular}{ccc}
\hline Gain Score & Category \\
\hline$g \geq 0,7$ & High & \\
\hline $0,7>g \geq 0,3$ & Moderate & Low \\
\hline$g<0,3$ & L & \\
\hline
\end{tabular}

\section{RESULTS AND DISCUSSION}

The results of this classroom action research show that the score of learning outcomes in the topic of the reproductive system has increased. This can be seen from the average score that is getting bigger in table 2. Besides that, the interpretation of the gain score in table 3 also shows that there is an increase in the moderate and high categories. The graph also shows that the increase occurred.

Table 2. Average Score of Student Learning Outcomes for Each Cycle

\begin{tabular}{cc}
\hline Step & Average Score \\
\hline Pre-Cycle & 20.56 \\
\hline Cycle 1 & 60.42 \\
Cycle 2 & 83.89 \\
\hline
\end{tabular}

Table 3. Results of Interpretation of Gain Scores for Each Cycle

\begin{tabular}{ccc}
\hline Step & Gain Score & Category \\
\hline Pre cycle - cycle 1 & 0.50 \\
Cycle 1 - cycle 2 & 0.59 \\
Pre cycle - cycle 2 & 0.79 \\
Moderate & High \\
\hline
\end{tabular}

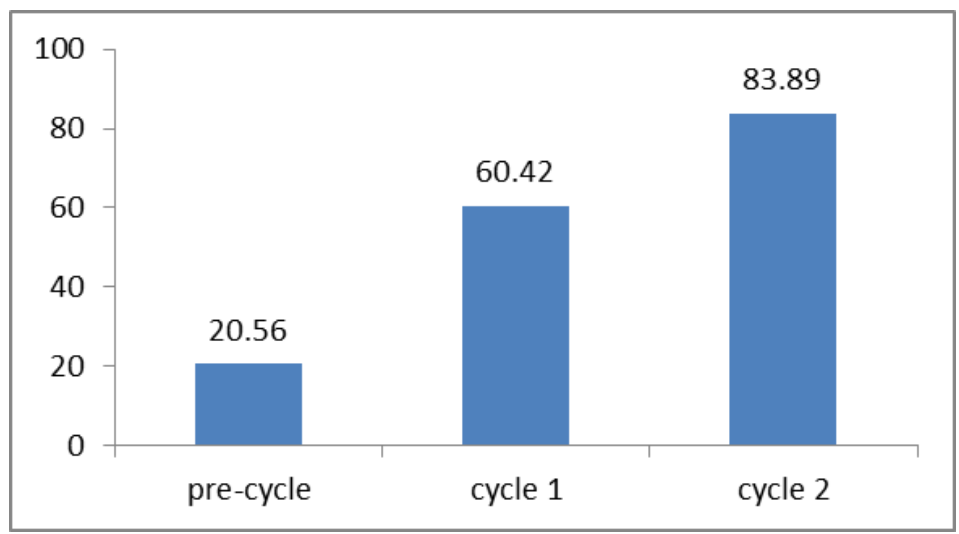

Figure 2. Average Student Learning Outcomes

Improved student learning outcomes are caused by the use of mind maps. That is because mind map is a media that can unite concepts so that they are easy to understand
(Chang, Chiu, \& Huang, 2018; Ihlebæk \& Larsson, 2018; Polat et al., 2017; Ramdhani \& Muhammadiyah, 2015; Widiana \& Jampel, 2016). In this context, the topic of the 
reproductive system has a high level of conceptual complexity. So the use of mind map media will make students easily understand the topic of the reproductive system.

In this topic there are some difficult concepts such as mitosis and meiosis cell division. The concept between meiosis and mitosis is often confused because it is similar. This is a difficulty for students to understand cell division. The use of this mind map makes the difference between mitosis and meiosis clearly visible. And the link between the two concepts is clearly seen. This is important because students often experience misconceptions in natural science learning (Djanette \& Fouad, 2014; Ichsan, Dewi, Hermawati, \& Iriani, 2018; Keleş \& Kefeli, 2010).

The use of mind maps is also useful for students in understanding the topic of reproductive organs in humans and their functions. On this topic often students do not understand because of the many Latin languages. The use of mind maps in the discussion of reproductive topics is very helpful for teachers in explaining various concepts. In mind map usage can be seen in the image below. In addition to learning outcomes, many things need to be improved on students. For example, to improve Higher Order Thinking Skills (HOTS) which are still low in students at Junior High School 1 South Tambun who have been studied previously (Ichsan, Hasanah, Aini, Ristanto, \& Miarsyah, 2019; Ichsan, Sigit, \& Miarsyah, 2019, 2019, 2019). That is because natural science learning in schools is still dominant using the teacher center approach. The teacher center approach and tools that are not based on HOTS are very difficult to improve learning outcomes, moreover to improve HOTS in accordance with the results of research that has been done previously at Junior High School 1 South Tambun (Ichsan, Iriani, \& Hermawati, 2018; Ichsan, Iriani, Hermawati, \& Dewi, 2019; Ichsan, Sigit, \& Miarsyah, 2018). That is because, in natural science learning, students are required to be able to analyze problems not only memorize existing concepts.

Good natural science learning must also be accompanied by an increase in student behavior. Not only learning outcomes but must also be able to change student behavior for the better after natural science learning (Gardeli et al., 2017; Krettenauer, 2017). This change is considered quite difficult because of the limitations of the existing media in schools. This also becomes the basis for the continued development of learning media and evaluation tools that are more contextual for students (Charoencha, Phuseeorn, \& Phengsawat, 2015; Kartikaningtyas, Kusmayadi, \& Riyadi, 2018).

\section{CONCLUSION}

Based on the results of this study concluded that mind map learning media can improve student learning outcomes on the topic of the human reproductive system. The gain score is moderate and high. This is because mind maps can help students in learning that requires a lot of understanding of concepts. The recommendation of this study is to further develop learning tools to improve learning outcomes.

\section{REFERENCES}

Agustini, L. (2019). Effect of Student Teamss Achievement Division (STAD) on Mathematical Learning Results in SDLB Surabaya. International Journal for Educational and Vocational Studies, 1(6). 554-559.

Ariyanto, S. R., Munoto, M., \& Muhaji, M. (2019). Development of Psychomotor Domain Assessment Instrument on Brake System Competence in SMKN 1 Jetis Mojokerto. International Journal for Educational and Vocational Studies, 1(6). 585-590.

Chang, J. H., Chiu, P. S., \& Huang, Y. M. (2018). A sharing mind map-oriented approach to enhance collaborative mobile learning With digital archiving systems. International Review of Research in Open and Distributed Learning, 19(1), 1-24.

Charoencha, Ic., Phuseeorn, S., \& Phengsawat, W. (2015). Teachers development model to authentic assessment by empowerment evaluation approach. Educational Research and Reviews, 10(17), 2524-2530. https://doi.org/10.5897/ERR2015.2243

Coley, J. D., \& Tanner, K. (2015). Relations between intuitive biological thinking and biological misconceptions in biology majors and nonmajors. $C B E$ Life Sciences Education, 14(1), 1-19. https://doi.org/10.1187/cbe.14-06-0094

Daghistan, B. I. A. M. (2016). Mind Maps to Modify Lack of Attention among Saudi Kindergarten Children. International Education Studies, 9(4), 245-256. https://doi.org/10.5539/ies.v9n4p245

Djanette, B., \& Fouad, C. (2014). Determination of University Students' Misconceptions about Light Using Concept Maps. Procedia - Social and Behavioral Sciences, $\quad 152, \quad 582-589$. https://doi.org/10.1016/j.sbspro.2014.09.247

Garcia, L. C. (2015). Environmental Science Issues for Higher- Order Thinking Skills (HOTS) Development: A Case Study in the Philippines. In Biology Education and Research in a Changing Planet (pp. 45-54). https://doi.org/10.1007/978-981-287-524-2

Gardeli, A., Vosinakis, S., Englezos, K., Mavroudi, D., Stratis, M., \& Stavrakis, M. (2017). Design and Development of Games and Interactive Installations for Environmental Awareness. EAI Endorsed Transactions on Game-Based Learning, 4(12), 1-11. https://doi.org/10.4108/eai.8-12-2017.153402

Ichsan, I. Z., Dewi, A. K., Hermawati, F. M., \& Iriani, E. (2018). Pembelajaran IPA dan Lingkungan: Analisis Kebutuhan Media Pembelajaran pada SD, SMP, SMA di Tambun Selatan, Bekasi. JIPVA (Jurnal Pendidikan IPA Veteran), 2(2), 131-140. 
https://doi.org/10.31331/jipva.v2i2.682

Ichsan, I. Z., Hasanah, R., Aini, S., Ristanto, R. H., \& Miarsyah, M. (2019). Higher Order Thinking Skills Assessment based on Environmental Problem (HOTS-AEP): Mendesain Evaluasi Pembelajaran Abad 21. Jurnal Biotek, 7(1), 14-26.

Ichsan, I. Z., Iriani, E., \& Hermawati, F. M. (2018). Peningkatkan Keterampilan Berpikir Tingkat Tinggi (Higher Order Thinking Skills) Pada Siswa Sekolah Dasar Melalui Video Berbasis Kasus Pencemaran Lingkungan. Edubiotik: Jurnal Pendidikan, Biologi Dan Terapan, 3(02), 12-18.

Ichsan, I. Z., Iriani, E., Hermawati, F. M., \& Dewi, A. K. (2019). Students Worksheet Based on Anti Corruption and Higher Order Thinking Skills (SWACHOTS): Mengembangkan Pembelajaran Lingkungan Abad 21. Edubiotik: Jurnal Pendidikan, Biologi Dan Terapan, 4(01), 1-8.

Ichsan, I. Z., \& Mulyani, S. W. W. (2018). Improving Students' Motoric Skills Through Demonstration Method in Recycling Plastic Waste. JPBI (Jurnal Pendidikan Biologi Indonesia), 4(2), 189-194. https://doi.org/10.22219/jpbi.v4i2.5890

Ichsan, I. Z., Sigit, D. V., \& Miarsyah, M. (2018). Learning Environment: Gender Profile of Students' Pro-Environmental Behavior (PEB) based on Green Consumerism. Tadris: Jurnal Keguruan Dan Ilmu Tarbiyah, $3(2)$, 97-107. https://doi.org/10.24042/tadris.v3i2.3358

Ichsan, I. Z., Sigit, D. V., \& Miarsyah, M. (2019). Environmental Learning Based on Higher Order Thinking Skills: A Needs Assessment. International Journal for Educational and Vocational Studies, 1(1), 21-24. https://doi.org/10.29103/ijevs.v1i1.1389

Ichsan, I. Z., Sigit, D. V., \& Miarsyah, M. (2019). Students ' Higher Order Thinking Skills in Environmental Learning: Develop Assessment Based on Green Consumerism. Journal of Educational Science and Technology (EST), $\quad$ 5(1), $\quad$ 9-19. https://doi.org/10.26858/est.v5i1.7848

Ichsan, I. Z., Sigit, D. V., \& Miarsyah, M. (2019). Students Higher Order Thinking Skills: Analyze, Evaluate, Create Green Consumerism Solution in Environmental Learning. International Journal for Educational and Vocational Studies, 1(4).

Ichsan, I. Z., Sigit, D. V., Miarsyah, M., Azrai, E. P., \& Heryanti, E. (2019). Students' pro-environmental behavior and environmental learning outcomes based on green consumerism. Jurnal Pendidikan Biologi Indonesia, 5(1), 109-116. https://doi.org/10.22219/jpbi.v5i1.6447

Ihlebæk, K. A., \& Larsson, A. O. (2018). Learning by Doing:
Perspectives on social media regulations in Norwegian news organizations. Journalism Studies, 19(6), 905-920.

https://doi.org/10.1080/1461670X.2016.1239184

Karaarslan, G., \& Teksöz, G. (2016). Integrating Sustainable Development Concept into Science Education Program Is Not Enough; We Need Competent Science Teachers for Education for Sustainable Development--Turkish Experience. International Journal of Environmental and Science Education, 11(15), 8403-8425.

Kartikaningtyas, V., Kusmayadi, T. A., \& Riyadi, R. (2018). The effect of brain based learning with contextual approach viewed from adversity quotient. Journal of Physics: Conference Series, 1022.

Keleş, E., \& Kefeli, P. (2010). Determination of student misconceptions in "photosynthesis and respiration" unit and correcting them with the help of cai material. Procedia - Social and Behavioral Sciences, 2(2), 3111-3118. https://doi.org/10.1016/j.sbspro.2010.03.474

Khoiriyah, A. J., \& Husamah, H. (2018). Problem-based learning: Creative thinking skills, problem-solving skills, and learning outcome of seventh grade students. JPBI (Jurnal Pendidikan Biologi Indonesia), 4(2), 151-160. https://doi.org/10.22219/jpbi.v4i2.5804

Krettenauer, T. (2017). Pro-Environmental Behavior and Adolescent Moral Development. Journal of Research on Adolescence, 27(3), 581-593. https://doi.org/10.1111/jora.12300

Leong, S. S. M., Mohd Said, H., Shahrill, M., \& Perera, J. S. H. Q. (2016). Using lesson study to enhance meaningful understanding on the topic of pressure. International Journal of Environmental and Science Education, 11(15), 8425-8435.

Lubis, R. R., Irwanto, I., \& Harahap, M. Y. (2019). Increasing Learning Outcomes and Ability Critical Thinking of Students Through Application Problem Based Learning Strategies. International Journal for Educational and Vocational Studies, 1(6). 524-527.

Polat, O., Yavuz, E. A., \& Tunc, A. B. O. (2017). The effect of using mind maps on the development of maths and science skills. Cypriot Journal of Educational Sciences, 12(1), 32-45.

Ramdhani, M. A., \& Muhammadiyah, H. (2015). The Criteria of Learning Media Selection for Character Education in Higher Education. In International Conference of Islamic Educatios in Shoutheast Asia (pp. 1-9).

Saido, G. A. M., Siraj, S., DeWitt, D., \& Al-Amedy, O. S. (2018). Development of an instructional model for higher order thinking in science among secondary 
school students: a fuzzy Delphi approach. International Journal of Science Education, 40(8), $847-866$.

https://doi.org/10.1080/09500693.2018.1452307

Vidergor, H. E., \& Krupnik-Gottlieb, M. (2015). High order thinking, problem based and project based learning in blended learning environments. In Applied Practice for Educators of Gifted and Able Learners (pp. 217-232).

https://doi.org/10.1007/978-94-6300-004-8_11

Wicaksono, A. G. C., Minarti, I. B., \& Roshayanti, F. (2018). Analysis of students' science motivation and nature of science comprehension in middle school. Jurnal Pendidikan Biologi Indonesia, 4(1), 35-42. https://doi.org/10.22219/jpbi.v4i1.5354

Widiana, I. W., \& Jampel, I. N. (2016). Improving Students' Creative Thinking and Achievement through The Implementation of Multiple Intelligence Approach with Mind Mapping. International Journal of Evaluation and Research in Education (IJERE), 5(3), 246-254.

Yeung, S. yin S. (2015). Conception of teaching higher order thinking: perspectives of Chinese teachers in Hong Kong. Curriculum Journal, 26(4), 553-578. https://doi.org/10.1080/09585176.2015.1053818 